\title{
As Transformações da Elite Eclesiástica no Bispado do Maranhão
}

Wheriston Silva Neris ${ }^{1}$

\section{Resumo}

Este artigo, com título inspirado em Weisz (1988), se apoia sobre uma análise prosopográfica do corpo clerical no Bispado do Maranhão durante a segunda metade do século XIX. O objetivo deste estudo é analisar as transformações no modo de exercício da carreira sacerdotal combinadas às modificações da composição social do clero e aos impactos de reformas institucionais sobre o modo de recrutamento, seleção e progressão nessa esfera profissional. Por meio do exame de trajetórias clericais, o estudo procurou apreender as mediações concretas através das quais os projetos e reformas institucionais tomaram corpo nesse recorte. Os resultados apresentados permitem apoiar a tese de que houve uma tendência à convergência entre as características dos agentes e as expectativas associadas ao posto. Essa conformação aparece com mais evidência nas oportunidades abertas para alunos brilhantes oriundos de categorias sociais modestas do interior, cujas propriedades os conduziam a investirem tudo na instituição à qual eles deviam tudo, e fora da qual suas possibilidades de ascensão social eram limitadas.

Palavras-chave: Elite Eclesiástica Maranhão; Trajetórias; Reformas Institucionais

1 Professor do Curso de Ciências Humanas, Universidade Federal do Maranhão/UFMA, Campus São Bernardo. Email: wheristoneris@yahoo.com.br. 


\section{The Transformations of the Ecclesiastical Elite in the Bishopric of Maranhão}

\section{Abstract}

This article, which has the title inspired by Weisz (1988), is based on a prosopographic analysis of clerical body in the Bishopric of Maranhão during the second half of the 19th century. The aim of this study is to analyze the changes in the mode of exercise the priestly career combined with changes in the clergy social composition and with the impacts of institutional reforms on the mode of recruitment, selection and progression in this professional sphere. Through examination of clerical careers, the study sought to observe the concrete mediations through which projects and institutional reforms took shape. The results allow supporting the thesis that there was a trend towards convergence between the characteristics of the agents and the expectations associated with the position. This conformation appears more evident in the opportunities open to bright students coming from humble social categories of the interior of state, whose properties led them to invest everything in the institution to which they owed everything, and out of which their opportunities for social advancement were limited.

Keywords: Ecclesiastical élite; Bishopric of Maranhão; Trajectories; Institutional reforms

\section{Introdução}

Ao fim do século XIX, ainda sob controle do Império, a estrutura da Igreja no Brasil ainda era bastante simples. Por volta de 1889, havia somente 12 dioceses e 13 bispos em todo o país. Dessas dioceses, somente 9 (nove) contavam com seminários voltados para a formação eclesial, alguns dos quais em franco processo de decadência. Para uma população em torno de 14 milhões de 
habitantes, distribuídos ao longo de um vasto território, havia aproximadamente 700 padres - a maior parte destes, seculares, ou seja, sacerdotes que estavam vinculados a uma instância administrativa da Igreja organizada em torno de um bispo (uma diocese). A presença de membros do clero regular nesse período era bastante limitada, resultado das inúmeras restrições à reprodução das ordens presentes na legislação do governo imperial, o que exigiu que a Igreja se apoiasse quase que exclusivamente sobre os padres seculares e sobre a sua limitada rede de formação. Além de poucas dioceses, a Igreja dispunha de um reduzido número de paróquias, a maior parte delas, muito distantes umas das outras e impossibilitadas de estabelecerem contatos contínuos e regulares entre si (BRUNEAU, 1974; SERBIN, 2008).

Como a instituição do padroado dava ao governo o controle de praticamente todas as áreas de interesse da Igreja (da construção de igrejas ao pagamento do clero, da nomeação de bispos a aprovação de documentos emanados de Roma), pelo menos até o final do século XIX, a instituição eclesial dispunha de um baixíssimo grau de autonomia em relação à política. Assim, na medida em que o padre poderia ser considerado tanto como um funcionário público, pago pelos cofres do governo, quanto um membro de uma burocracia paralela e importada, a Igreja, os sacerdotes estavam submetidos a um duplo sistema de lealdades que era fonte potencial e permanente de conflitos (CARVALHO, 1996, p. 165). Cabe ressaltar, no entanto, que embora fosse considerada parte da burocracia do estado, a Igreja não era nada mais do que um departamento ordinário do governo no século XIX (os párocos recebiam na década de 1870 um salário equivalente ao do proletariado burocrático), ocupando uma posição de menor importância, quando comparada aos demais setores burocráticos eminentes que eram os "matizes da ordem", como os magistrados e o exército (Id. Ibid, 1996, p. 155). Isso que não deixou de causar efeitos sobre a capacidade de atração exercida pela carreira eclesiástica, em seu sistema de recrutamento e sobre o exercício do posto clerical. 
Distantes de Roma e à frente das dioceses, os bispos possuíam uma grande liberdade de ação e exerciam sua autoridade praticamente de forma independente. É difícil não ver a Igreja Católica nesse momento um universo compósito de práticas pastorais e estilos episcopais variantes conforme as diferentes histórias e quadros diocesanos. Assim, quando o Vaticano intensificou os investimentos para estreitamento dos vínculos entre Roma e a Igreja no Brasil, principalmente a partir do papado de Pio IX (1846-1878), não era de se estranhar que um dos primeiros objetos de disputa fosse a questão da composição do episcopado (pode-se mencionar a questão do bispo eleito do Rio de Janeiro em 1833). De fato, a escalada dos conflitos entre Estado e Roma suscitou diversos pontos de fricção, entre os quais, o mais conhecido foi sem dúvida a chamada Questão Religiosa, ocorrida em 1874, e que envolveu os bispos de Olinda (Dom Vital Maria Gonçalves de Oliveira) e do Pará (Dom Antônio Macedo Costa) (MARTINS, 2002). Dentro da Igreja, eventos como o Concílio Vaticano I (1869-1870) e também a lenta afirmação da realização de estudos em Roma ou em outros polos culturais centrais como um dos canais mais valorizados de acesso aos postos eclesiásticos superiores (SEIDL, 2008), certamente ajudaram nesse processo de estreitamento de vínculos horizontais, entre bispos brasileiros, e verticais com Roma. Isso que está no princípio da constituição de um front de bispos renovadores ou reconstrutores que, entre outros aspectos, encabeçarão a romanização da Igreja Brasileira.

Como em boa parte dos trabalhos disponíveis sobre as transformações da Igreja católica no período, neste estudo, a instância diocesana constituiu o quadro pertinente de análise escolhido para refletir sobre as redefinições institucionais e a recomposição das relações de poder no seio da Igreja. A diocese é uma unidade administrativa definida como circunscrição territorial na qual um bispo exerce seus poderes sobre a Igreja local. Essa escolha se justifica pelo fato de que era nesse nível intermediário da hierarquia que funcionava a maior parte dos organismos de gestão da Igreja, sendo ele o que melhor se ajusta ao exame das configurações organizacionais sucessivas do poder hierárquico 
em suas conexões com o espaço local e internacional. 0 referencial empírico selecionado foi o da diocese do Maranhão em um recorte cronológico preciso (segunda metade do século XIX) que se caracterizou pela introdução de diversas reformas institucionais e abarcou uma série de transformações na estrutura social e política do país, as quais não deixaram de ter reflexos sobre a composição da elite em questão. A posição estudada na configuração institucional católica é a do sacerdote dada a sua delicada função de mediador entre as verdades transmitidas pela instituição e as exigências e expectativas variadas dos fiéis com os quais ele mantinha contato constante, ora entrando em conflito, ora compartilhando crenças e esperanças (LAGROYE, 2006). 0 objetivo aqui é combinar a dialética da história da inserção institucional da Igreja Católica no Maranhão, as percepções formuladas sobre o posto e sua função, às modificações na composição social do clero na segunda metade do século XIX. Trata-se de tentar apreender as mediações concretas através das quais os projetos e reformas institucionais tomaram corpo nesse recorte.

Embora exista uma farta bibliografia sobre a Igreja Católica no Brasil, são aparentemente raros os estudos sobre a composição e origem social do clero no século XIX (para uma avaliação semelhante, consultar Carvalho, 1996, p. 166). Em nível internacional, a maior parte dos trabalhos sobre a evolução do recrutamento sacerdotal se concentra em contextos e situações históricas muito distintas do caso observado (CAMPICHE \& BOVAY, 1979; ROY, 1983; VERNARD, 1968; pode-se mencionar também as observações de CHARLE, 2013). No Brasil, os estudos que serviram de inspiração e cujos referenciais de pesquisa e as condições estudadas estavam mais próximos desta pesquisa trataram das transformações da profissão médica (CORADINI, 1997) e das elites do exército e do episcopado no Estado do Rio Grande do Sul (SEIDL, 1999; 2008). Em nível local, além das obras de religiosos sobre a história da igreja local, poucos estudos permitem um diálogo (MENDONÇA, 2011; SILVA, 2012). Diversos trabalhos centrados em outras condições nacionais e 
profissionais forneceram recursos analíticos importantes (PINTO, 1975; 1976, SUAUD, 1974; CHARLE, 1980; WEISZ, 1988; MUEL-DREYFUS, 1983), apesar de se distanciarem muito do estudo de uma elite culturalmente dominante numa sociedade periférica e importadora de ideologias, filosofias e tecnologias institucionais dos países centrais (CORADINI, 1997). Isso que não existe sem efeitos sobre o emprego de esquemas analíticos formulados em outros contextos empíricos. Os principais marcos teóricos do trabalho são fornecidos pelas perspectivas metodológicas inovadoras presentes nos trabalhos de Pierre Bourdieu $(1987 ; 1994 ; 1996 ; 2007)$ e de pesquisadores inspirados em seu esquema analítico, bem como pela sociologia das instituições (LAGROYE, 2006; 2009; LAGROYE \& OFFERLÉ, 2011) e a renovação dos estudos sociológicos sobre grupos dirigentes no Brasil (CORADINI, 2008; SEIDL \& GRILL, 2013, HEINZ, 2006).

Para realização deste trabalho, as fontes básicas de informações sobre o clero local foram os livros de registro e os processos de habilitação para ordenação sacerdotal presentes no acervo do Arquivo Público do Estado do Maranhão ${ }^{2}$, os trabalhos de intelectuais da igreja sobre a história eclesiástica regional ${ }^{3}$ e os

2 (1) Autos de habilitação de gênere, que consistiam em processos através dos quais era investigada a origem do pretendente ao sacerdócio através da inquirição de testemunhas sobre a legimidade da filiação, a vida religiosa e a "qualidade" e "limpeza" de sangue; (II) Autos de Vita et Moribus, que reúne as investigações sobre a vida, os costumes e a conduta civil do ordenando também através da investigação junto a testemunhas; (III) Autos de patrimônio, que reúne informações sobre o tipo de bem (propriedade) transferido pelo pretendente ao sacerdócio para a Igreja (NERIS, 2009; MICELI, 1988).

3 (1) “A Igreja no Maranhão" (1877) e também “O dicionário Histórico-Geográfico da Província do Maranhão", publicados por César Augusto Marques (1977); 2) "Apontamentos para a História Eclesiástica", de D. Francisco de Paula e Silva publicado em 1922 e discorrendo sobre a história da Arquidiocese de 1612 a 1907; 3) "A História Eclesiástica do Maranhão", de D. Felipe Condurú Pacheco, datada de 1968 e 4) "A História da Arquidiocese do Maranhão", de autoria de Mario Martins Meirelles, publicada em 1972 por ocasião da comemoração do tricentenário da fundação da Arquidiocese do Maranhão. Além disso, existem dois trabalho de cunho biográfico a respeito de Dom Luiz Raimundo da Silva Brito, o qual teria sido o primeiro arcebispo da Olinda: o primeiro fora escrito por Condurú Pacheco (1954) e o segundo por Álvaro Urubatan (1994). 
hebdomadários que circulavam no período em pauta (especialmente os jornais católicos 0 Eclesiástico [1852-1862], 0 Cristianismo [1854-1855] e o Civilisação [1880-1890]). Recorrendo a esse conjunto de fontes, pude construir um dossiê prosopográfico sobre 84 indivíduos que ingressaram na instituição eclesial na segunda metade do século XIX, distribuídos ao longo dos últimos três bispados. Os principais indicadores utilizados foram a origem geográfica, profissão do pai, o tipo de patrimônio transferido à Igreja quando da ordenação, a idade da ordenação, o tipo de formação recebida pelo clérigo e os postos ocupados ao longo da carreira. Conquanto o estado da documentação (quantidade e condições de leitura das fontes) e as próprias escolhas e limites metodológicos de construção do questionário biográfico tenha incidido sobre a caracterização dessa coletividade existência de lacunas, acesso desigual a informações conforme o indivíduo, etc. - considero que o estudo dos membros do corpo eclesial constitui um ponto de partida para uma pesquisa sobre as condições sócio-profissionais do clero e para a explicação de algumas características do catolicismo e das transformações na carreira eclesiástica. No texto que segue, discuto, em primeiro lugar, os significados associados ao sacerdócio na segunda metade do XIX; em seguida, elenco elementos que permitem caracterizar a história da inserção da instituição eclesial na região e o espaço dos possíveis eclesiásticos; por fim, discuto as características sociais do clero apreendidas através da enquete prosopográfica (HEINZ, 2006; CHARLE, 2013) conduzida junto às fontes de informação mencionadas. Ao final, extraio conclusões sobre as transformações da carreira eclesiástica frente às modificações na sua composição e as reformas institucionais realizadas no recorte em pauta. 


\section{Os significados do sacerdócio na segunda metade do século XIX}

A busca por informações na imprensa oitocentista a respeito do exercício e das percepções sobre o posto sacerdotal se depara com um numeroso conjunto de denúncias e críticas de segmentos letrados a respeito das tomadas de posição dos bispos (infalibilidade papal, questão religiosa), do fanatismo dos sacerdotes, apontados como responsáveis pelo obscurantismo do povo, e da corrupção dos padres mais inclinados à política do que ao exercício clerical. Essas críticas eram recorrentes entre os membros do grupo literário que atuou entre 1870 e 1890 e que, envoltos pelo movimento de ideias na Europa, protagonizaram diversos debates na imprensa local sobre temas diversos como a abolição, a maçonaria, o ensino, a família e o papel da mulher, o casamento e a própria igreja (MERIAN, 1988; MARTINS, 2004; LACROIX, 2008). Não foram poucas as querelas entre os integrantes dessa geração, como Celso Magalhães, Aluísio de Azevedo e Manuel Bithencourt, e sacerdotes como o Padre Raimundo Alves Fonseca e Tolentino Guedelha Mourão nas páginas de periódicos prestigiosos como $O$ País, $O$ Diário do Maranhão, e que se mesclavam à uma série de outras problemáticas e posições político-partidárias que caracterizavam as publicações jornalísticas regulares nesse recorte.

Uma querela entre clericais e anticlericais no XIX

Talvez um dos embates mais representativos dessa diferenciação tenha sido aquele que opôs Celso Magalhães ao padre Raimundo Alves Fonseca a respeito da publicação do drama de Rangel Sampaio "Evangelho e Syllabus" em 22 de outubro de 1876 no jornal "O País". A peça questionava o "Syllabus", documento publicado pelo Papa Pio IX (18461878), avaliada como retrógrada e fanática, opondo-a à uma igreja autêntica, aberta, generosa e sem hipocrisia. 
Sua publicação na imprensa desencadeou o conflito (MERIAN, 1988). De um lado temos Celso da Cunha Magalhães, cujo nome está associado à literatura de critica social do século XIX. Sua projeção nacional se deve em grande medida ao pioneirismo de sua obra como abolicionista. Em nível regional tornou-se bastante conhecido também pela condução da denúncia contra Ana Rosa Viana Ribeiro acusada pelo assassinato de uma criança num processo que ficaria conhecido como crime da baronesa, no final de 1876. Nascido em 1849, em Viana, Celso Magalhães era filho de um tenente-coronel. Criado pelos avós paternos, sua educação ficou sob a responsabilidade de professores particulares e do seu avô, formado pela Universidade de Coimbra. Em 1868 segue para a capital da província (São Luís) com a finalidade de preparar-se para o ingresso na Faculdade de Direito. Em 1869 ingressa na Faculdade do Recife, ambiente acadêmico de tendência republicana e cientificista. Desde 1867 publica versos e Crônicas na imprensa maranhense e já na Província de Pernambuco, publica seu primeiro livro em 1873 (Versos). Além do direito, também se interessava sobre diversos temas como arqueologia, folclore, história da arte, química, música e teatro. Obtendo o bacharelado em 1873, retorna ao Maranhão, sendo nomeado promotor publico na capital. Membro de uma geração de jovens intérpretes locais de ideias em circulação na Europa, Celso Magalhães dispôs-se ao envolvimento em uma série de lutas ideológicas empregando os recursos do direito, da literatura e do ensaio nas principais arenas de disputa intelectual e política do momento: os jornais. A consequência de sua tentativa de incriminar e julgar a mulher do chefe do Partido Liberal, no final de 1876, foi a sua demissão do cargo de promotor 'a bem do serviço público, em 1878' (COSTA, 2011; MERIAN, 1988, p. 148). Noutro lado, temos o sacerdote Raimundo Alves da Fonseca, a respeito do qual os relatos memorialísticos dão conta de suas propriedades intelectuais e sua total dedicação aos interesses da Igreja. Nascido em 1842 uma família humilde de Santo Antônio do Jeromenha, província do Piauí, Fonseca talvez seja um dos exemplos mais ilustrativos de um novo conjunto de clérigos oriundo de núcleos familiares com poucas possibilidades de direcionar seus rebentos para o ingresso em profissões prestigiosas e que se beneficiam do lento processo de diversificação da com- 
posição social do clero regional. Provavelmente graças aos contatos do seu pai, que exercia a função de empregado público na secretaria da polícia, Fonseca obteve patrocínio pelo governo provincial para prosseguimento dos seus estudos no seminário de Santo Antônio. Como "pensionista", ingressou no seminário em 1860, sendo ordenado em 1867. Reconhecido como estudante distinto e disciplinado e gozando de boas relações com o corpo docente e o bispo, nesse mesmo ano de 1867 assumiu o cargo de vice-reitor do seminário menor, passados apenas 5 meses de "ministério paroquial" em uma freguesia do Piauí. Em 1870 foi aprovado para o concurso de lente (docente) de Filosofia do Liceu Maranhense expondo sua tese baseada em São Tomás de Aquino. Fundou juntamente com os sacerdotes Raimundo da Purificação dos Santos Lemos e Theodoro A. Pereira Castro o colégio da Imaculada Conceição, que funcionou até 1876. Nomeado como professor de História Sagrada e Eclesiástica em 1877, foi também convocado para assumir a direção do Seminário Maior. Nesse mesmo ano foi promovido à função de capelão capitão do exército. Entre os membros de sua geração formada no seminário entre os anos 1862 e 1878, Fonseca se destaca pelo envolvimento progressivo e trabalhoso na aquisição de disposições morais e intelectuais condizentes com os novos ideais organizacionais. Isso que o habilitou a exercer funções de representação intelectual do catolicismo local, e ajuda a entender como ele pôde envolver-se nessas querelas com anti-clericais, seja nas décadas de 1870, seja com os redatores do Jornal 0 Pensador, no início da década de 80 (MONTELLO, 1978; NERIS, 2011a; RODRIGUEZ, 1982).

O eixo desses conflitos incluía uma diversidade de problemáticas legítimas da política e da cultura, não cabendo aqui examiná-las aprofundadamente. 0 que interessa destacar é que, antes de desavenças pessoais e pontuais, esses debates expressavam, na realidade, o choque entre facções ideológicas divergentes do mundo letrado, dotados de redes, ideologias, vinculações internacionais e modos de socialização cada vez mais distintos. Se, a princípio, essas oposições envolviam principalmente o clero e os letrados, tendo nos jornais os principais meios de disputa, com o passar do tempo elas não apenas incluíram novas problemáticas, 
como também serviram de matrizes ideológicas para uma série de outras disputas sobre concepções de sociedade e política no Maranhão Republicano - praticamente todas essas hipóteses se inspiram no trabalho de Coradini (1998). É sem dúvida desse processo que surgiu um polo intelectual católico que, principalmente durante os primeiros decênios do século XX, se envolveu em disputas pelo controle das instâncias locais de consagração e reprodução cultural, sobretudo o controle do espaço universitário (NERIS, 2011b). Porém, no presente trabalho, concentro o estudo desse processo de diferenciação sobre as transformações morfológicas do clero e as reformas institucionais que durante o recorte em pauta operaram mudanças tanto nas exigências de dedicação ao posto, quanto ampliaram as possibilidades de carreira eclesiástica.

Dentro dos meios eclesiais, o principal efeito do acirramento de debates com os anti-clericais foi o de intensificar a preocupação com a questão da regeneração intelectual e moral do clero oitocentista. Para fazer frente então às recorrentes criticas e denúncias quanto à ignorância e imoralidade dos sacerdotes, dentro dos dispositivos de ajustamento do clero, dois instrumentos de enquadramento ganhavam relevo: a formação ofertada pelos seminários diocesanos e a ordenação sacerdotal.

Os seminários eram, sem dúvida, centrais para a afirmação de um ideal sacerdotal que era o fruto de uma construção histórica e social de longo termo e realizada em várias etapas. Pelo menos desde o século IV esse modelo sacerdotal começa a se desenhar. Nesse processo, o Concílio de Trento $^{4}$ (1545-1563) foi fundamental para reafirmar a necessidade de o padre deter uma conduta irrepreensível, em estreita conexão com o papel

4 Através do "Concílio de Trento" (1545-1563), a igreja remodelou o clero, clarificou a doutrina, conservou os sete sacramentos, afirmou a presença real na eucarística, iniciou a redação de um catecismo, obrigou os bispos a residir no local de seu bispado, os padres a pregar e decidiu a criação dos seminários (NERIS, 2009). 
de mediador que lhe era atribuído (BERAUD, 2006, p. 24-25). 0 objetivo, como dito, era moldar um novo tipo de padre, virtuoso, isolado da política, desembaraçado de laços sociais e de conduta inquestionável, como preconizava Trento, sem muito êxito na antiga colônia portuguesa, é verdade, há pelos menos 03 séculos. Estando encarregados de realizar uma formação profissional que permitisse aos futuros ministros exercer sua função de celebração do culto e dos sacramentos, pregação e ensino, os seminários constituiriam peças-chave nos dispositivos de aquisição e definição do estado sacerdotal ${ }^{5}$.

No Bispado do Maranhão, a introdução dos seminários esteve no princípio das principais modificações no sistema de recrutamento sacerdotal analisadas aqui. Se o costume anterior era o de um sacerdote acompanhar individualmente a progressão de um pupilo pelas sucessivas fases de aquisição do habito sacerdotal, com a criação dos seminários maior (1838) e menor (1863), a nível regional e, sobretudo após a imposição da passagem pelos seminários como critério para o exercício da função eclesiástica - durante o bispado de Dom Manuel Joaquim da Silveira (1851-1861) - adquirir o estatuto de sacerdote se tornava um investimento cada vez mais laborioso e controlado pela instituição. A obrigatoriedade da passagem pelos seminários como condição para obter a ordenação sacerdotal teve então duas consequências importantes para o que se discute aqui: em primeiro lugar, se até metade do sé-

5 Ingressando em tenra idade e submetendo-se desde cedo às regras, costumes e valores da cultura organizacional (MICELI, 1988), o seminarista recebia diversos cursos teóricos e práticos e, participando no cotidiano das práticas religiosas, aprendia por observação e prática, tanto a modelar seu comportamento conforme observado e exigido pelos seminaristas mais idosos, padres e diretores do seminário, quanto começava a entender as lógicas de seleção internas ao espaço eclesiástico. A incorporação cotidiana do ofício realizada pela materialidade do seminário, pelas vestimentas e objetos litúrgicos, por meio da repetição dos gestos, da inserção em uma coletividade e pela ruptura com o mundo externo, etc. ajudam a descrever o caráter totalizante e sacrificial com que se traduz o investimento para obtenção do estatuto sacerdotal, para incorporação no papel e a aquisição de disposições para o exercício da posição ocupada. 
culo XIX o recrutamento dava-se unicamente através da transmissão individual e da posse de uma rede de contato com membros importantes, capazes de orientar as generosidades do mecenato do Estado, a partir da criação dos seminários, abriu-se maior espaço para a valorização de atributos internos ao espaço clerical, como aqueles vinculados ao reconhecimento pela dedicação aos estudos e as redes de relações construídas ao longo do percurso na instituição. Em segundo lugar, essas exigências normativas não apenas demandaram um maior investimento em tempo e energia dos aspirantes ao sacerdócio, como também, ao colocar lado a lado agentes com disposições e aspirações diversas, contribuiu ao aprofundamento das disputas e competições internas - o resultado prático disso foi a formatação de uma geração sacerdotal bastante combativa, interna e externamente.

Entre os diversos dispositivos e técnicas a que era submetido o futuro padre, nenhum marcava tão profundamente essa tentativa de separação do mundo externo quanto o sacramento da ordenação. A ordenação consiste no rito de instituição que, tal como o define Pierre Bourdieu (1989, p. 140-142), constitui um verdadeiro ato mágico pelo qual a instituição separa, qualifica, consagra, agrega e investe oficialmente a um agente da autoridade para exercício da função. Em outros termos, trata-se de uma maneira de impor uma ordem, uma operação de divisão que institui uma divisão legitimada, magicamente produzida e juridicamente garantida, do mundo social. É assim que a ordenação não apenas inscreve o indivíduo na ordem da sucessão apostólica, operando uma delegação do carisma institucional, como também operava um corte biográfico na vida dos agentes que a ele se submetiam. Nesse período, os procedimentos para essa investidura institucional estavam definidos no Concílio de Trento e detalhados nas Constituições Primeiras do Arcebispado da Bahia, publicadas em 1707.

Como determinavam essas normas, os aspirantes ao sacerdócio deveriam passar por um longo processo de seleções e ritos exa- 
minatórios prévios para admissão na corporação eclesiástica. Primeiramente, deveriam adquirir todas as ordens sacramentais, as quais eram divididas em vários graus: 04 menores e 03 sacras. As ordens menores, Ostiário, Leitor, Exorcista e Acólito, eram assim designadas por que os poderes que conferiam não versavam imediatamente sobre objetos consagrados concernentes ao sacrifício, senão sobre os ministérios inferiores relativos ao culto divino. As Sacras, Subdiácono, Diácono e Presbítero (ou sacerdote), eram designadas também de maiores por que conferiam poder imediato em ordem aos objetos sagrados pertencentes ao sacrifício - aqueles que as recebessem estariam irrevogavelmente consagrados ao ministério do altar e obrigados a guardar perpétua castidade (SALINAS ARANEDA, 2006). A maior parte das leis exigia apenas a idade mínima (22 para subdiácono, 23 para diácono e 25 para ordens de missa), ter recebido as quatro ordens menores, saber latim, cantar e pronunciar, ler as horas canônicas no breviário, conhecer os principais mistérios da fé, os sacramentos, as censuras eclesiásticas e ter noções de casos de consciência (MONTEIRO, 2003). Todas essas diferentes etapas eram pontuadas por ritos de iniciação com atributos espetaculares, dificilmente encontrados em outras instituições. A aquisição da última ordem, a de presbítero, constituía um período forte na dinâmica da diocese, sendo geralmente bastante solenizado e celebrado na catedral de maneira fáustica para marcar o espírito coletivo. Tudo isso que permite ver o quanto a opção pela carreira sacerdotal constituía um fato social total no sentido que lhe dá Marcel Mauss, na medida em que ele afetava todos os aspectos da vida de um indivíduo, tornando, inclusive, delicada a separação entre o que seria trabalho e fora do trabalho (independentemente do que fizesse, o individuo continuaria a ostentar o título de padre).

Embora a formação clerical e a ordenação fossem instrumentos fundamentais para diminuição das distâncias entre a reforma que se desejava implantar e a realidade, os comportamentos desviantes foram frequentes. Desde o período colonial, 
atuando relativamente livres da autoridade da Igreja, historicamente os padres envolveram-se a fundo na política, compravam fazenda e escravos (CARVALHO, 1996, p. 166) e, violando os votos de castidade, tiveram vários filhos (SERBIN, 2008, p. 11; MENDONÇA, 2007; 2011). Disso se reclamavam os redatores do jornal $A$ Imprensa em 1861 quando afirmavam que: "Muito difícil há de ser, entre nós, um vigário que tome sobre os ombros outra gloriosa tarefa, a não ser a cabala eleitoral, [...] transformado em chefe de partido [...] torna-se ateador da guerra, faz que a metade do seu rebanho viva em contínua disputa com a outra metade, é o pastor mandado em lobo [...] cabalam, intrigam, transigem e não recuam ante os meios mais depravados, contanto que triunfem e suplantem o adversário" (MEIRELLES, 1960, p.242). Apesar de que a estrutura estivesse se tornando cada vez mais normatizada, as atividades sacerdotais eram marcadamente plurais, dado o acúmulo de funções compósitas, insólitas e até mesmo incongruentes exibidos por diversos ocupantes desse posto.

Como o próprio Estado impedia a expansão institucional da igreja (sobretudo a multiplicação de circunscrições administrativas) e o clero ainda não tinha sofrido uma redução tão drástica do seu quantitativo quanto aquela que ocorreria no século $\mathrm{XX}$, o "tempo livre" de que dispunha o sacerdote abria um amplo leque de possibilidades de atuação fora dos limites institucionais. A importância dessa variável, o tempo, se mostra com clareza quando comparamos esse momento com a situação atual na qual a Igreja dispõe de uma gigantesca estrutura de postos e funções que tende a sobrecarregar e a consumir praticamente todo o tempo do clero em atividade internas ou chanceladas pela instituição. No século XIX, essa disponibilidade de tempo, combinada à carência dos rendimentos, como mencionado, em certos casos forçava o sacerdote ao exercício de uma série de outras atividades, tais como: professor, jornalista, escritor, poeta e/ou político a nível local - enfim, um impressionante número de atividades subsidiárias e profanas. 
Em síntese, internamente à Igreja ou não, as representações sobre as atividades do clero e os modos de exercício do posto sacerdotal mostram que muito além das funções de vigário e cura, aos quais se vincula o exercício das funções sacramentais (sua associação a lugares de culto fixo e sua ligação aos aparelhos objetivos da celebração, para se remeter ao tipo-ideal do clero de que falava Max Weber), as atividades do padre poderiam ser definidas pela sua pluri-funcionalidade. A depender do ângulo selecionado, como observou Thomas Bruneau, o padre poderia ser considerado desde um funcionário público, principalmente quando possuía uma paróquia; membro de uma família fazendeira e até uma espécie de empregado de irmandades (BRUNEAU, 1989). Desse modo, o caso dos membros da igreja católica nesse recorte poderia muito bem se prestar à discussão da multiposicionalidade dos membros da classe dominante (BOLTANSKI, 1973), dada a divisão das atividades de sacerdote com inúmeros outros afazeres. Conquanto já não figurasse entre as posições mais eminentes nesse recorte e o próprio acesso ao posto demandasse um maior investimento, o exercício do sacerdócio ainda dispunha de certa atratividade, especialmente entre os segmentos mais pobres da sede e das paróquias do interior que, como pretendemos demonstrar, poderiam ver na obtenção do sacerdócio uma via para obtenção de posições de destaque no espaço político e cultural.

\section{Uma civilização diocesana longe de Roma}

Por um lado, esse modo de exercício clerical constituía a herança da inserção histórica do catolicismo no Brasil e no Maranhão. Como já sugerido, desde o início da colonização, a estrutura geográfica da Igreja brasileira era bastante limitada, a julgar pela extensão territorial do continente. Durante mais de um século a diocese da Bahia era a única existente para a colônia e foi necessário aguardar 1676 para que fossem fundadas as do Rio e Olinda. Somente em 1677 foi criada a diocese do Maranhão, 
desmembrada da Arquidiocese de São Salvador da Bahia e tornada dependente (sufragânea) do Arcebispado de Lisboa até 1827. Instalada em uma terra de missão, a criação da diocese do Maranhão consistiu no estabelecimento de um foco difusor de dioceses e se alinhava à criação de uma estrutura administrativa consoante à autonomia geográfica e política do Estado do Maranhão e Grão-Pará - criado em 1621 e com sede na cidade de São Luís, essa unidade abrangia todo o território que vai hoje do Ceará ao Amazonas (CABRAL, 2008, p. 63) - e aos objetivos da Coroa para a região. Em 1719, foi desmembrado todo o território com que foi criado o Bispado de Belém do Pará. Desde então a área da diocese do Maranhão abrangia os limites das Províncias do Maranhão e do Piauí. Um mapa do bispado do Maranhão no século XVIII permite uma observação da extensão territorial da diocese.

Mapa do Bispado do Maranhão XVIII

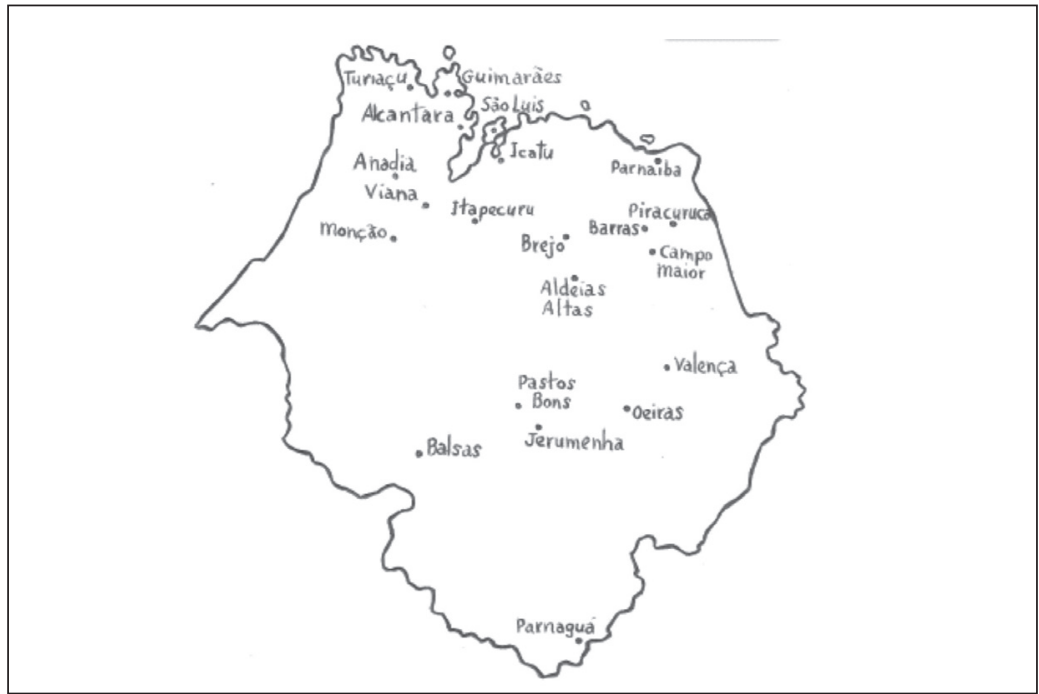

Fonte: MENDONÇA, 2011, p. 98. 
Distante da ortodoxia romana, esse pequeno fragmento de uma igreja universal desenvolveu características e propriedades que se distinguiam em muito do catolicismo romano (MARIN, 1995). Mais ligado à herança cultural e religiosa portuguesa, embora esse componente tenha se reproduzido sob uma baixíssima mediação da instituição eclesiástica, esse espaço social era fortemente dominado pelos repertórios religiosos que ordenavam toda a vida cotidiana, regulamentavam as relações entre homens e mulheres, pais e filhos, pobres e ricos, dominantes e dominados, definindo ainda as relações com o trabalho, a vida, o sofrimento e a morte. De fato, tendo o patronato régio reduzido a influência de Roma, é nas raízes do catolicismo popular português do fim da Idade Média, transferido ao Brasil sem a clericalização e a dogmatização de Trento, que é necessário procurar as características da religiosidade nordestina. Esse catolicismo não reformado, adaptado às condições de uma sociedade nova e que impregnou todo o período colonial e que atribuía uma função decisiva aos santos, às devoções, às procissões e às festas (MARIN, 1995, p. 48). É desse catolicismo importado e híbrido que se trata aqui.

Durante esses séculos, diferentes ordens religiosas passaram pela região (Jesuítas, Carmelitas, Beneditinos e Franciscanos) deixando marcas na memória, história e identidade da diocese. Conquanto as ordens dominassem a Igreja Brasileira desde os primórdios da colonização, nota-se que a partir do século XVIII ocorre uma forte ascensão dos padres seculares na composição do corpo sacerdotal brasileiro (SERBIN, 2008, p. 42). É o que se pode notar no estudo realizado Pollyanna Gouveia Mendonça (2011) sobre a diocese do Maranhão no século XVIII. De 1710 a 1780, a pesquisadora mostra que nada menos que 197 agentes concluíram os processos de ordenação sacerdotal a nível regional. Comparando a composição do clero local com outras dioceses, a exemplo da metrópole, onde teria ocorrido uma ruptura no fluxo de ordenações nesse mesmo período, nota ainda que o caso do bispado maranhense era inteiramente outro. Conforme 
se pode depreender de sua pesquisa, o afrouxamento dos critérios de seleção do clero (dispensas de impedimentos: "mulatismos"; "mixturas"), as vacâncias de bispos na diocese e o emprego de diversas estratégias pelos pretendentes ao sacerdócio para burlarem as regras e procedimento de ordenação, constituem fatores explicativos pertinentes tanto sobre as taxas de vocações na diocese do Maranhão, quanto sobre as lógicas práticas por meio das quais o recrutamento sacerdotal promovia uma abertura para agentes que não se enquadravam nos requisitos institucionais.

Infelizmente não existem ainda pesquisas sobre a composição do corpo clerical da diocese do Maranhão para a primeira metade do XIX, mas é muito provável que essa maleabilidade do sistema de recrutamento tenha se mantido. Porém, apesar dessa abertura, quando se chega ao período contemplado nesta pesquisa, a quantidade de sacerdotes já não era tão grande quanto ao do século anterior e o desnível entre o numero de paróquias e o de padres se aprofundava rapidamente, conforme se poderá perceber nos relatórios produzidos pelos Bispos assim que assumiram a diocese do Maranhão, reproduzidos no trabalho de Felipe Condurú Pacheco (1969).

Padres e paróquias nos relatórios dos bispos

0 relatório de 1860, apresentado pelo Bispo D. Manuel Joaquim da Silveira, por exemplo, indica haver 76 paróquias no bispado (53 no Maranhão e 23 no PI), sendo que "no Maranhão, além dos membros do "cabido" e auxiliares (26), havia 72 sacerdotes para 372 mil habitantes; no Piauí, 36 sacerdotes para 186 mil" (PACHECO, 1969, p. 245). Já em 1862, em resposta a circular do Ministro do Império, o referido prelado indica haver "52 paróquias no Maranhão e 22 no Piauí", sem indicar a quantidade de sacerdotes. No bispado de D. Frei Luiz da Conceição Saraiva,o relatório de 1871 
indica existirem 79 paróquias em toda a diocese, sendo que 53 pertenciam ao Maranhão e 26 ao Piauí. Havia, então, 90 padres na diocese e 10 de ordens religiosas. "Dizia o prelado necessitar de 103 sacerdotes seculares, sem contar os coadjutores e os substitutos eventuais" (PACHECO, 1969, p. 341). Já no relatório de 1872, haviam falecido 07 padres diocesanos e 02 regulares, e sem que houvessem ordenações nesse período, a diocese teria ficado com 93 padres no Bispado. Em 1876, estando vacante a sede, o relatório do vigário capitular indica existirem 104 presbíteros nas duas províncias: 10 regulares e 94 seculares. 0 relatório de 1880, apresentado pelo Bispo D. Antônio Candido de Alvarenga, indica haver 56 paróquias no Maranhão e 29 no Piauí, dispondo de 95 sacerdotes, dos quais 85 seculares e 6 regulares. 0 relatório de 1888 dá conta da existência de 94 paróquias, sendo que 64 na província do Maranhão, 28 na do Piauí e 2 na do Ceará. Em toda a diocese havia "104 igrejas e 14 capelas, maiores ou menores, mais ricas ou mais pobres". "Para todos os ministérios da diocese" haviam "somente 88 sacerdotes seculares e 02 regulares", o que corresponde a uma distribuição de aproximadamente 8.333 habitantes para cada clérigo (8.522 se levarmos em conta somente os seculares).

\section{Estrutura dos postos eclesiásticos e o universo dos possíveis}

A caracterização do universo de possibilidades de carreira ofertadas àqueles que ingressavam nessa civilização diocesana ao longo da segunda metade do XIX, constitui um meio privilegiado para a compreensão sobre os investimentos e a atratividade do métier sacerdotal no espaço social.

A matrícula geral do clero da diocese do Maranhão organizada em 1886 mostra que 104 sacerdotes foram originários ou tiveram passagem pelo Maranhão na segunda metade do século XIX (APEM, N. 334, sem data). A organização da lista exibe bem os critérios de classificação que organizavam a 
distribuição de poder dentro da diocese. Em primeiro lugar o Bispo, Dom Antônio Cândido Alvarenga, originário de São Paulo, idade de 50 anos, sagrado bispo do Maranhão desde 1876 e tendo assumido a diocese desde 1878. Seu bispado foi um dos mais longos da diocese e se prolonga até o final do século XIX. Em seguida, em torno dessa figura e como que em ordem de prestígio, os sacerdotes são listados num sentido que vai da proximidade ao centro da diocese às paróquias mais distantes. Entre aqueles que foram listados em seguida, vê-se que ocupam (não raro, simultaneamente) as seguintes posições: vagas no cabido diocesano (arcipreste, cônego, beneficiados); reitores, professores e ecônomos de um dos seminários diocesanos (menor e maior), membros da câmara eclesiástica (promotor, amanuense, escrivão interino); párocos vinculados à catedral, à capelania militar e/ou à alguma paróquia localizada na sede do bispado do Maranhão (São Luís) ou em uma de suas imediações. Todos aqueles que possuíam títulos de bacharel ou doutorado também estavam contemplados, embora um deles tenha partido em direção à diocese do Rio de Janeiro, o que talvez explique a sua posição (20ํ) na enumeração dos sacerdotes. A única exceção em relação à essa concentração geográfica dos listados foi o caso do sacerdote Honório José Saraiva, originário do Piauí e que, cônego da catedral, foi "dispensado da residência para ocupar os cargos de Vigário Forâneo da Província do Piauhy e Pároco da Parochia do Amparo da cidade de Therezina". Como veremos, a vigararia forânea consistia em uma posição importante na administração de uma vasta diocese como a do Maranhão que agrupava os territórios da província do Maranhão e piauí. Com pequenas variações, a partir da posição n. 27, a lista segue agrupando os sacerdotes com base em dois critérios aparentes: da Província do Maranhão em direção ao Leste (Piauí); do norte em direção ao sul. Ao final da lista encontram-se referências aos poucos membros de ordens ainda vivos no Maranhão (carmelita, mecedário, capuchinho) e outros que ainda estavam em etapa de formação para ordenação (tonsurados). 
Esses critérios de organização da lista de religiosos dão a ver as lógicas de distribuição dos postos na hierarquia católica a nível regional. No topo da instância diocesana estava o bispo. Em torno a ele, reunia-se uma assembleia que o auxiliava nas tarefas administrativas e no governo da diocese, especialmente nos casos em que houvesse vacância no cargo. Quando isto ocorria, esse colégio de clérigos escolhia entre os membros um substituto denominado de vigário capitular ou vigário geral. Esse grupo central consistia então em uma assembleia que ritualizava o centro simbólico e político da diocese. Entre os membros do cabido estavam aqueles que estavam vinculados às paróquias localizadas na Ilha de São Luís, que ocupavam funções prestigiosas como membro da Cúria Episcopal Diocesana, diretoria espiritual ou posições mais caracteristicamente intelectuais como professor (lente) e reitor e vice-reitor dos seminários. 0 exercício de alguma função nessas instâncias centrais da diocese significava, por seu turno, um considerável aumento no raio de alcance da influência e atuação de seu ocupante, dentro e fora do espaço eclesial. Por um lado, sem estarem sobrecarregados com funções de administração pastoral e expansão institucional no interior da província, esses sacerdotes poderiam acumular funções na esfera eclesial, como já mencionado. Noutro, uma vez que esses postos estavam localizados na sede da província, para o conjunto do clero, as possibilidades de encontrar alguma outra ocupação nesse espaço eram bem maiores, fosse como professores, poetas, jornalistas ou até mesmo como políticos.

Dada a extensão territorial da diocese ${ }^{6}$, o Bispado do Maranhão estava dividido em sub-unidades administrativas chamadas de vigararias gerais. Por exemplo, havia uma Vigararia Geral cuja

60 território da Diocese, pouco habitado na maior parte, apresentava uma superfície de 694.442 quilômetros quadrados, mais ou menos, com uma população de 750.000 almas, segundo os melhores cálculos. A diocese limitava-se ao Norte com o Oceano Atlântico, ao Sul com a Archidiocese da Bahia, a Leste com as Dioceses de Fortaleza e Olinda, e a Oeste com as de Belém do Pará e Goyaz". 
sede era a capital da Província do Maranhão e uma Vigararia Geral Forânea cuja sede era localizada na cidade de Oeiras no Piauí. Ambos os vigários eram subordinados diretamente ao Bispo. Ao vigário forâneo cabia a inspeção dos párocos e demais eclesiásticos da província, devendo prestar relatórios anuais ao Bispo. Pode-se recorrer a um relatório institucional de 1872 para caracterizar a distribuição das freguesias no Bispado (APEM, n.ํㅜ 335, 1872). Conforme esse relatório de 1872, havia 83 freguesias, cada uma delas devendo conter um sacerdote engajado em sua administração pastoral. Como a maior parte dos rendimentos paroquiais advinha da cobrança pelos serviços litúrgicos prestados, chamados de emolumentos, que complementavam os parcos rendimentos recebidos do império (as côngruas), o retorno propriamente material dessas freguesias poderia mostrar-se bastante desigual e até mesmo insatisfatório, principalmente naquelas inúmeras freguesias pobres das regiões mais afastadas da sede do Bispado. Contudo, não se pode excluir aqui o fato de que ser vigário em uma freguesia na qual o padre foi batizado e da qual era orginado a maior parte dos seus parentes tanto poderia ser prestigioso individual e coletivamente, quanto, em alguns casos, permitiria a colaboração na gestão e manutenção dos interesses da parentela. Apresento a seguir um quadro das diferentes freguesias e sua distribuição entre as províncias do Maranhão e Piauí. 
AS TRANSFORMAÇÕES DA ELITE ECLESIÁSTICA NO BISPADO DO MARANHÃO

Tabela 1: Classificação das oitenta e duas freguesias em que se divide o Bispado do Maranhão (1872).

\begin{tabular}{|c|c|c|}
\hline $\begin{array}{c}\text { Provín- } \\
\text { cias }\end{array}$ & № & Nome das Freguesias \\
\hline \multirow[b]{3}{*}{ 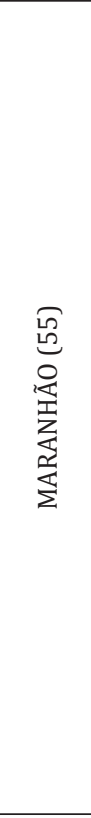 } & & Ilha \\
\hline & 08 & $\begin{array}{l}\text { N. S. da Victória da Cathedral; N. S, da Conceição; S. J. Baptista; S. Joaquim } \\
\text { do Bacanga; Santa Filomena do Cutim; S. da Luz do Passo do Lumiar; S. } \\
\text { José dos Indios; S. João Baptista dos Vinhaes }\end{array}$ \\
\hline & 47 & \begin{tabular}{|l} 
Terra firme \\
S. Mathias de Alcantara; S. João de Cortes; Santo Antonio e Almas; S. Ben- \\
to; S. Bento de Bacurituba; S. Vicente Ferrer de Cajapió; Santo Ignácio de \\
Pinheiro; S. José de Guimarães; Santa Helena; S. João Baptista de Cururu- \\
pu; S. Francisco Xavier de Tury-açu; S. Francisco Xavier de Monção; S. José \\
de Penalva; N. S. da Conceição de Viana; N. S. de Nazareth do Meary; N. \\
S. da Graça do Arary; Santa Maria de Anajatuba; S. José do Periá; N. S. da \\
Conceição do Icatu; N. S. do Rosário; N. S. da Lapa e Pias de San Miguel; N. \\
S. das Dores do Itapecuru-Mirim; N. S. da Piedade de Coroatá; Santa Rita \\
e Santa Filomena do Codó; S. Luiz Gonzaga do Alto Meary; S. Sebastião da \\
Vargem Grande; N. S. das Dores da Chapadinha; N. S. das Barreirinhas; N. \\
S. da Conceição da Tutoya; N. S. do Arayoses; S. Bernardo; N. S. da Concei- \\
ção do Brejo; Santa Anna do Burity; N. S. da Conceição e S. José de Caxias; \\
S. Benedito de Caxias; N. S. de Nazareth da Tresidella; S. José dos Mattões; \\
S. Sebastião de Passagem Franca; S. Bento de Pastos Bons; N. S. da Con- \\
ceição da Manga; S; Felix de Balsas; N. Senhora da Victória; Santa Cruz da \\
Barra do Corda; Senhor do Bom-fim da Chapada; Santa Thereza do Porto \\
Franco; S. Pedro de Alcantara da Carolina; N. S. de Nazareth do Riachão.
\end{tabular} \\
\hline 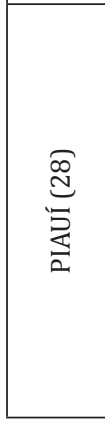 & 28 & $\begin{array}{l}\text { N S. do Amparo da Theresina; N. S. das Dores de Tehresina; Capella cura- } \\
\text { da de N. S. dos Humildes; N. S. dos Remédios da União; N. S. da Conceição } \\
\text { das Barras; Santo Antonio de Campo-Maior; N. S. da Graça do Parnahyba; } \\
\text { N. S. dos Remédios do Peripery; N. S. da Conceição de Pedro Segundo; } \\
\text { Senhor do Bom-fim do Principe Imperial; N. S. dos Desterro de Marvão; } \\
\text { Sant’Anna da Independência; N. S. do Ó de Valença; N. S. da Victória de } \\
\text { Oeiras; N. S. das Mercês de Jaicós; N. S. dos Remédios de Picos; São Gon- } \\
\text { çalo do Amarante; Santo Antonio de Jeromenha; N. S. da Ceonceição de } \\
\text { Uhyea; S. Raimundo Nonnato; S. João do Piauhy; N. S. do Livramento de } \\
\text { Parnaguá; N. S. da Conceição do Corrente; Senhor Bom Jesus da Gurgué; } \\
\text { Santa Filomena. }\end{array}$ \\
\hline
\end{tabular}

Fonte: Arquivo Público do Estado do Maranhão, Acervo da Arquidiocese do Maranhão, Setor de Códices, LIVRO de Registro das Freguesias do Maranhão e Piauí (n. 335, 1872). 
Para o que importa reter aqui para a caracterização da organização administrativa da diocese, essa lógica de distribuição das posições permite ressaltar algumas distinções pertinentes no sistema de ganhos e possibilidades abertas ao ingressante no espaço eclesial nesse recorte. Dois princípios de hierarquização subdividem esse sistema de postos em dois grandes blocos: de um lado, um polo dominante composto pelas posições centrais da diocese, compreendendo além do cargo episcopal, os postos das paróquias da Ilha de São Luís e circunvizinhanças, as posições no cabido diocesano e onde eram recrutados ainda os componentes da Cúria Episcopal e do corpo docente e administrativo dos seminários; noutro polo, as funções paroquiais distribuídas ao longo da diocese (em "terra firme") e mais diretamente vinculadas às tarefas de expansão institucional e administração pastoral. Enquanto a sede administrativa concentrava o maior número de sacerdotes e despertava o maior interesse dentro do corpo eclesial, fenômeno esse que pode ser divisado pelos concursos para freguesias da ilha ou pela concorrência aos postos prestigiosos do cabido, as freguesias distantes da sede diocesana sofriam maiores percalços frente à ausência de sacerdotes. Essa histórica carência da cobertura institucional da Igreja era agravada ainda por uma série de outros fatores conjunturais, tais como o envelhecimento e o falecimento de sacerdotes (um relatório de 1878 mencionava o falecimento de nada menos que 37 padres na segunda metade do XIX) ou as solicitações de deslocamento em direção à outras dioceses, como ocorreu no final do XIX quando houve uma crise no bispado de Dom Antônio Cândido Alvarenga e diversos sacerdotes se removeram para a diocese do Rio de Janeiro.

Enfim, essas observações permitem apoiar a tese da existência de uma homologia entre o espaço dos possíveis na instituição e a estrutura mesma de divisão entre as diferentes regiões que compunham o território do bispado. Assim, os critérios de distribuição e divisão dessas posições institucionais mantinham forte correspondência com os critérios de classificação social e 
inclusive geográfica do espaço em questão. Como observado em vários outros sistemas de relações sociais (BOURDIEU, 1975; CHARLE, 1977; PINÇON \& PINÇON CHARLOT, 1997), dessa homologia resulta que as divisões que atravessam o espaço social e geográfico, eles mesmos estruturados e hierarquizados, possam ser lidas no sistema de posições e status que caracterizam uma instituição, um ofício ou mesmo bairros.

\section{As origens sociais do clero no Bispado do Maranhão.}

Conforme Conduru Pacheco (1969), ao longo da segunda metade do século XIX, foram ordenados 115 sacerdotes na diocese do Maranhão distribuídos da seguinte maneira ao longo de três bispados: a) 38 ordenados no bispado de D. Manuel Joaquim da Silveira (1852-1861); b) 46 no bispado de D. Frei Luiz da Conceição Saraiva (1862-1878) e c) 31 no bispado de D. Antônio Candido de Alvarenga (1878-1898). Tomando de empréstimo esse critério de divisão cronológica da história da igreja, considerei que esses marcos temporais permitiriam acompanhar as transformações da carreira pelos diferentes estratos geracionais do clero. Com base na transcrição e sistematização dos dados obtidos no livro de ordenações, pude examinar 108 desses casos (dos 115 mencionados acima). No que tange especificamente às origens diocesanas destes, observa-se que apenas 78 padres (dos 108 casos de sacerdotes que recolhemos) eram originários da diocese do Maranhão. Trinta deles advinham das dioceses de Bahia (04), Ceará (05), Pará (10), Pernambuco (10) e Portugal (01). Essa observação importa para indicar que as fontes básicas de informação sobre a ordenação do clero (autos processuais e livro de ordenação), não oferecem uma indicação precisa sobre a quantidade de clérigos que chegaram desenvolveram sua carreira na diocese, o que nos interessa mais diretamente. Em todo caso, foi possível construir um dossiê prosopográfico reunindo informações sobre as origens sociais de 84 sacerdotes: além dos 78 casos mencionados de padres nascidos e ordenados na dio- 
cese, incluímos mais 06 de sacerdotes que haviam obtido ordens em outras dioceses e retornaram para o Bispado do Maranhão. Esclarecido esses critérios de definição da população, passo então à descrição dos indicadores selecionados.

No que tange especificamente às origens geográficas dentro do bispado, embora no geral se apresente uma grande dispersão das freguesias de origem dos sacerdotes - somando um total de 33 freguesias distintas - verifica-se que a província do Maranhão e, principalmente, as localidades mais centrais do bispado, em torno da ilha de São Luís, concentravam as principais zonas de recrutamento. Como essas regiões tinham a maior densidade populacional, reunindo as principais atividades produtivas, era natural que se impusessem como principais focos vocacionais. Ao longo dos bispados, no entanto, a tendência foi a da lenta diversificação das origens geográficas, principalmente no período do último bispado, quando o percentual de sacerdotes oriundos das zonas localizadas a oeste e ao sul da circunscrição superou aquele das regiões de recrutamento tradicional. É o que se pode notar quando cruzamos informações sobre as 09 freguesias mais representativas com as restantes. Enquanto para o primeiro período (1852-1861) a predominância daquelas era da razão de três quartos; no segundo período (1862-1878), ocorre um nivelamento (19 contra 18), até que no último bispado (18781898) esse padrão se inverte (13 contra 18).

Quanto à profissão paterna, é preciso enfatizar a insuficiência desse indicador como índice das origens sociais dos sacerdotes. Além do fato de que a profissão consistia em apenas um entre tantos outros títulos que respaldavam uma posição social (CORADINI, 1997), é também a relativa imprecisão de algumas classificações recolhidas nos processos que dificulta a análise (por vezes a profissão dos pais é evocada nos processos de investigação da seguinte maneira: "vivem de suas lavouras", "eram lavradores", "vivem de propriedade de terras e gado", "lavram e comerciam", etc.). Ao lado dessas definições, certamente, encontramos outras 
classificações mais claras como aquelas dos processos de filhos de militares (Tenente, Capitão, Tenente Coronel, Coronel) ou mesmo aquelas menos prestigiosas como Ourives, Ferreiro, Alfaiate, empregado público, professor de primeiras letras, guarda livro de comércio e comerciantes. Obtendo informações acerca da profissão paterna de 69 casos (dos 84 disponíveis), a descrição de suas posições sociais apresenta aqui um caráter muito mais ilustrativo.

Em uma região de fronteira e de caráter predominantemente agrícola, como era o território do Bispado do Maranhão, como era de se esperar, entre os 69 casos examinados, havia um predomínio de filhos oriundos de famílias de agricultores $(n=35)$, seguidos pelos de militares (19 de 69 com informações disponíveis). Logo a seguir encontravam-se os filhos de empregados públicos e professores de primeiras letras (7), seguidos dos de Comerciantes e Guarda livros do comércio (05) e de pessoas vinculadas a ofícios mecânicos, tais como Ourives, Ferreiros e Alfaiates (03 de 69 casos recolhidos). Para o restante dos casos em que não foi possível a apreensão da profissão paterna, há 10 casos em que pude encontrar referências unicamente à mãe, abrangendo qualificações que vão de "ofício de costuras e serviços domésticos", "negócios de fazenda", "vivia de seu trabalho". Entre esses 10 casos, 07 são de sacerdotes que enfrentaram dificuldades no processo de habilitação sacerdotal pela identificação dos chamados defeitos de origem, como eram classificadas as uniões não santificadas pela igreja. Exemplos de trajetórias sociais ascendentes, entre eles encontravam-se os sacerdotes Carlos Luís D’Amour, Luiz Raimundo da Silva Brito, Dorotheo Dias de Freitas, Francisco José Batista, Arthur César da Rocha e Silvino Angelo da Silva.

\section{Um oblato miraculado.}

"Aos nove anos fui para São Luís completar meus estudos. Era isto aos 18 de fevereiro de 1850, data em que cheguei àquela capital. Nunca tinha lá posto os pés. A viagem se fa- 
zia e ainda se faz por igarapés, depois através de um braço de mar e, por último, na baía de São Marcos. Guardo ainda na alma a primeira impressão do meu contato com o mar. (...) Conclui o curso primário em São Luís, com um professor particular e entre aos doze anos a estudar humanidades com o padre pernambucano Francisco Pedro de Sousa. (...) Aos treze anos estava pronto para entrar no seminário, então reformado por D. Joaquim da Silveira, Bispo do Maranhão (...). Morava eu, nesse tempo, com o meu padrinho Cônego Luís Raimundo da Costa Leite, a cuja memória ligo tanto apreço quanto à meu pai [em outro trecho da biografia, lê-se: certamente forte amizade reinava entre o pai do menino e o muito ilustre alcantarense, ex-pároco de São Bento, Cônego Costa leite]" (PACHECO, 1954, p. 19-20).

Essa descrição foi realizada por Luís Raimundo da Silva Brito, um dos poucos sacerdotes que chegaram à condição episcopal originados da diocese do Maranhão. Procedente de uma família com número elevado de filhos (era o sétimo de nove irmãos) esse "Sambentuense" nasceu em 1840, originário de uma família apresentada pelo seu biógrafo como "humilde" (seu pai era um português comerciante e criador e sua mãe se dedicava aos "serviços domésticos"). Começando os seus estudos teológicos no recém-reformado seminário, aos 18 anos (entre 1858-1861), Luiz Raimundo passou por todos os procedimentos requeridos para ordenação sacerdotal. Dispensado da "irregularidade ex defectum natalium" e concluída a constituição de seu patrimônio para a ordenação (uma morada de casa de taipa de propriedade de seu pai e outra do seu irmão, avaliadas em seiscentos mil réis), recebe as tonsura clerical e as ordens menores em setembro de 1869, o subdiaconato em 1860 e o diaconato em 1862. Sua ordenação, aos 24 anos, é assim descrita pelo seu ex-pupilo: "Raia, enfim, essa brilhante manhã do dia 19 de junho de 1864, que seria a gloriosa orientadora de toda a sua vida a seguir, como fora até então o marco miliário que ele sempre fitara no horizonte através de profícua e esperançosa adolescência. De joelho diante do seu Pontífice, junto ao altar santo da vetusta Sé Catedral, apresenta-o o Arcediago "a fim de ser ordenado para o ônus do presbítério" (...) Secundado o gesto sacramental do Pontífice, à coroa grave e majestosa do presbitério invoca o espírito criador e o faz baixar sobre o novo eleito, a fim de iluminar-lhe a 
inteligência e robuster-lhe a vontade, infundido-lhe "toda a virtude da graça sacerdotal". (...) Entregando-lhe agora o cálice com vinho e água e patena com a hóstia sobreposta, diz-lhe: "recebe o poder de oferecer sacrifícios a Deus e de celebrar missas, tanto pelos vivos, como pelos defuntos. Em nome do senhor". - Assim seja. (...) Da sua tríplice prostração exsurge, enfim, transfigurado, o jovem sambentuense. 0 humilde filho de humildes pais fora elevado à missão sublime de ministro, embaixador do Deus altíssimo (Pacheco, 1969, p. 30-33). Pouco tempo depois canta a primeira missa em sua terra natal (julho de 1864) junto aos parentes, conterrâneos e amigos. No primeiro concurso de que participa para uma paróquia (freguesia do Alto Mearim), perde a vaga para outro sacerdote, Padre Tomais de Morais Rego, antigo deputado provincial e vigário de outra paróquia. Criou em São Bento uma escola em 1866 entre os quais estudaram Urbano Santos, "eminente e inolvidável estadista que, como Vice-Presidente da República, administraria o Brasil" de quem se tornou padrinho, e o sacerdote "Osório Ataíde Cruz, falecido vigário na Capital Federal e deputado estadual no Maranhão" (p. 42). Embora conforme seu biógrafo não possuísse pendores para a Política, em 1868 Luiz Raimundo da Silva Brito recebe expressiva votação para vereador de São Bento, perdendo apenas por Guilherme Luís de Araújo, consagrado chefe político local. No ano seguinte, sendo nomeado para a freguesia de Rosário do Itapecuru, opta por abandonar o cargo político para dedicar-se inteiramente à nova posição. Em menos de 02 anos, Luís Raimundo foi nomeado para vice-reitor do seminário menor e aos 29 anos, já acumulava também o encargo de professor de Latim e Direito Canônico. Estando vaga a freguesia de Caxias em 1870, inscreve-se no concurso obtendo sucesso na ocupação da paróquia. Durante a sua permanência em Caxias, sustentou uma forte campanha contra a maçonaria a nível local, na página de diversos periódicos como o jornal Cruz e mesmo dentro da Igreja contra os padres "híbridos", debate esse que, como era frequente, se mesclava com uma série de disputas faccionais em diferentes níveis, dentro e fora da igreja local, e que se organizavam em diferentes redes, como se pode apreender na seguinte passagem de sua biografia: "Não concorreu pouco para esse estado de coisas a circunstância de haver Padre Brito, a instância de amigos seus, to- 
mado parte na luta política que naquela época agitava-se na Província entre as facções que dividiam o Partido Conservador, então dono da situação, entre Castristas e Maístas, tendo aqueles, chefiados pelo Conselheiro Gomes de Castro - o apoio ao Governo. Os Maístas - cujo chefe era o Conselheiro Silva Maia - tinham a simpatia do Padre Brito, o qual, graças ao seu prestígio e boas relações que mantinha com o Partido Liberal (adverso), muito influía na questão fortalecendo assim a facção a que era afeto" (p. 81). Nessa disputa Luís Raimundo não estava sozinho. Fazia ele parte de uma geração de oblatos que se destacou por suas tomadas de posição duras e radicais em defesa da instituição, entre os quais se enumeram sacerdotes formados em sua mesma geração (Tolentino Guedelha Mourão, Leopoldo Damasceno Ferreira, José Hemetério do Rego Brito, Fábio José da Costa, Raimundo Alves da Fonseca, etc.), durante o bispado de Dom Luiz da Conceição Saraiva (1862-1878). Entre 187677, o Padre Brito foi indicado como representante do colégio eleitoral de Caxias na Assembleia Legislativa Maranhense, onde os seus requerimentos tocavam principalmente em diferentes questões de interesse da igreja Em 1877 o jornal apóstolo publica a notícia de que o Padre Brito teria sido nomeado para a função de Vice-Reitor do Internato do Imperial Colégio de Pedro II e para a cadeira de Religião e História Sagrada. Em ambas as nomeações, encontra-se a assinatura de um "notável médico e educador maranhense", na ocasião, "reitor interino" do instituto imperial, e que é celebrado em obras de história eclesiástica regional como um dos representantes mais importantes do laicato católico no Maranhão Imperial: Dr. César Augusto Marques. Cônego desde 1888, Luiz Raimundo da Silva Brito foi promovido e sagrado bispo em 1901, vindo a ser o primeiro Arcebispo de Olinda. Faleceu em Recife em 1915.

Deslocando o foco para a formação obtida e a idade de ordenação dos sacerdotes ordenados no recorte em pauta, nota-se o quanto o seminário gerava uma forte homogeneidade quanto às trajetórias escolares. Os estudos primários e secundários foram realizados nos poucos centros de educação regional. Como já era de se esperar, quase a totalidade dos padres realizou seus estu- 
dos em seminários diocesanos. Quanto à escolarização superior, frente à inexistência de institutos ou faculdades no território, era necessário o deslocamento em direção a centros internacionais, fosse patrocinado pelo governo da província ou pela disposição de recursos da família. A principal modificação entre os poucos sacerdotes que ostentavam títulos universitários estava no deslocamento dos centros de formação de Coimbra para Paris e Roma, como se pode ver no quadro abaixo.

Tabela II: Clérigos com formação no exterior e instituições/localidades de obtenção.

\begin{tabular}{|c|c|c|}
\hline Período & CLÉRIGO & INSTITUIÇÃO \\
\hline \multirow[b]{2}{*}{$1852-1861$} & Joaquim Pereira Serva & \begin{tabular}{|llll} 
Doutorado em & Theologia & Dogmática & - \\
Universidade de
\end{tabular} \\
\hline & \begin{tabular}{|lll} 
Manoel & Tavares \\
Silva & & \\
\end{tabular} & \begin{tabular}{|lll} 
Doutorado em Theologia & Dogmática & - \\
Universidade de Coimbra & & \\
\end{tabular} \\
\hline \multirow{2}{*}{$1862-1878$} & \begin{tabular}{|l} 
José Raimundo da \\
Cunha
\end{tabular} & Doutorado em Theologia Dogmática em Roma \\
\hline & $\begin{array}{ll}\text { Tolentino } \\
\text { Mourão }\end{array}$ & $\begin{array}{l}\text { Doutorado em Teologia Dogmática; licenciatura } \\
\text { em argumentação pública }\end{array}$ \\
\hline \multirow{4}{*}{$1878-1898$} & $\begin{array}{l}\text { Joaquim Sampaio } \\
\text { Castelo Branco }\end{array}$ & $\begin{array}{l}\text { Doutor em Direito Canonico pela Academia } \\
\text { Pontifícia de São Apolinário em Roma e Bacharel } \\
\text { em Teologia pela Universidade Cathólica de Paris }\end{array}$ \\
\hline & $\begin{array}{|lll|}\begin{array}{l}\text { Dorotheu } \\
\text { Freitas }\end{array} & \\
\end{array}$ & Paris (Licenciado) \\
\hline & Alvaro José de Lima & Paris (Licenciado) \\
\hline & $\begin{array}{l}\text { Leopoldo Damasceno } \\
\text { Ferreira }\end{array}$ & Paris (Licenciado) \\
\hline
\end{tabular}

Fonte: Arquivo Público do Estado do Maranhão, Acervo da Arquidiocese do Maranhão, Setor de Códices, LIVRO de Registro das Freguesias do Maranhão e seus respectivos Colados e Coadjutores (n. ํ 336; sem data) e material diverso reunido pelo autor. 
6. As carreiras sacerdotais e a ascensão a postos de elite

Aqui resida talvez a principal dificuldade a ser enfrentada, uma vez que os mecanismos empregados para ascensão aos postos de elite eclesial envolviam a utilização de uma diversidade de critérios, recursos e trunfos sociais que não eram estritamente institucionais. A questão é que o baixo grau de autonomia organizacional da Igreja, como mencionado a princípio, tinha diferentes consequências sobre os critérios de ascensão no espaço hierárquico. Desse modo, conquanto a implementação de reformas técnico-organizacionais tenham operado alterações importantes no sistema de recrutamento, eles não se contrapunham às lógicas e critérios tradicionais como aqueles vinculados ao capital simbólico, às redes familiares e à proximidade com outras esferas. Antagônicos a longo termo, foi necessário aguardar a separação oficial entre Igreja e Estado para que os critérios internos de ascensão se impusessem sobre as lógicas heterônomas - muito embora os laços pessoais, o parentesco, o clientelismo e a amizade continuassem a ser decisivos entre os mecanismos agindo no interior da esfera religiosa (SEIDL, 2008). Até que isso ocorresse, os critérios de avanço na carreira continuaram a ser marcadamente híbridos, resultado da combinação variável de regras e codificações internas mais formais, ao emprego de recursos e princípios de hierarquização social intermitentes, extremamente amplos e multidimensionais, como se pode caracterizar o caso estudado.

Embora as condições propriamente profissionais não se constituam sozinhas enquanto recursos para ascensão à elite, esse fato não impede que se identifiquem alguns traços em comum a partir do exame dos itinerários sociais e profissionais dos sacerdotes. Para essa discussão dos mecanismos de acesso aos postos dominantes, recolhi informações mais detalhadas sobre os trajetos profissionais de 78 sacerdotes (dos 84 casos incluídos no dossiê prosopográfico). De modo geral, os percursos profissionais podem ser divididos em dois blocos: 0 primeiro reúne os agentes 
cuja carreira se distingue pela ocupação de postos nas áreas geograficamente mais periféricas e afastadas do centro diocesano (53 sacerdotes). Agrupando os agentes menos dotados de recursos sociais importantes, geralmente de origem humilde e vindos do interior, estes padres eram recorrentemente designados para o exercício pastoral em zonas do interior das províncias do Maranhão e Piauí. Exibindo apenas a formação obtida nos seminários e, muito provavelmente, não dispondo de vinculações pessoais importantes dentro e fora da hierarquia, os principais instrumentos que detinham para gerar visibilidade para si dentro da instituição eram a realização de obras materiais em benefício da igreja, organização de grupos ou movimento leigos, e todo um vasto conjunto de ações microscópicas pelas quais, como dizia Seid (2008) par outro contexto, os "agentes zelosos" dariam provas de empenho e fidelidade para com a concretização dos projetos a eles delegados e habilitavam-se para funções mais "desafiadoras". Enquanto alguns se mantinham vinculados a uma paróquia pelo resto da vida (párocos colados por concurso), outros, menos afortunados, eram mudados de localidade em localidade, a depender das necessidades institucionais. Envolvidos em tarefas de administração pastoral direta e expansão da diocese, esses presbíteros distribuídos pelas vilas do interior muito raramente chegavam a posições de destaque internamente e quando o faziam, esse avanço era pontuado por uma lenta e gradual evolução entre os vários postos subordinados.

O segundo percurso se distingue por agrupar agentes cuja ascensão na carreira eclesiástica era realizada de maneira mais rápida (em nossa amostra, 25 agentes se notabilizam por esse tipo de percurso) e que se concentravam nas zonas centrais do poder eclesiástico (paróquias da ilha de São Luís e circunvizinhanças, cargos no cabido diocesano, Cúria Episcopal). Entre eles encontramos os agentes que detinham títulos escolares superiores e circulação internacional (licenciado, doutor) e que se notabilizavam mais recorrentemente pelo exercício de funções intelectualizadas (lentes, reitores, escritores) e de representação ins- 
titucional interna e externa (tais como, redação de periódicos e publicação de livros). Antes de serem designados para essas funções, alguns deles exibem uma breve passagem por atividades paroquiais. Entre aqueles que anteriormente tinham dado provas de sua dedicação desde as fases iniciais do seminário, e que foram selecionados para a realização de estudos superiores, encontramos os mais cotados para a função de professores e reitores de seminário - alguns dos quais não chegavam sequer a serem designados para funções de administração pastoral (vigário, cura) no início da carreira. A maior parte desses agentes passou praticamente toda sua vida profissional ocupando simultânea ou sucessiva esses cargos de direção e representação corporativa, o que os permitiu adquirir muito precocemente a notabilidade pelas suas capacidades e competências, reconhecimento esse que se estende aos registros e fontes que nos restam de seus trajetos (homenagens póstumas, biografias).

Encontrando-se nas posições dominantes mais estritamente fundadas na instituição, entre esses agentes era jogada a autoridade estatutária que assegurava não somente o domínio sobre outras posições e seus ocupantes, como também o poder sobre as próprias instâncias de reprodução do corpo eclesiástico - como se pode notar através dos concursos para cargos eclesiásticos que analise em minha dissertação (NERIS, 2009). Numa situação em que é difícil dissociar o poder específico ligado às posições dominantes, do ocupante da posição considerada, aqueles que chegaram a se apropriar dessas funções constituíram, sem dúvida, o principal polo dominante na hierarquia. Apesar de nenhuma biografia sintetizar essas vias da carreira sacerdotal, as trajetórias de sucesso que apresento à frente, todas elas celebradas na memória da instituição, permitem ilustrar essas condições de progressão e êxito na carreira.

Antes, porém, caberia refletir sobre a relação entre as possibilidades de ascensão na carreira eclesiástica e o investimento em atividades políticas pelos ocupantes do posto. Os estudos sobre 
a evolução da atividade política do clero nos cargos de Deputado Geral e Senado mostram que, embora essa inserção seja mais consistente durante primeiro reinado e nas regências, a ocupação de cargos políticos por sacerdotes se manteve ao longo de todo o século XIX (SILVA, 2012). Infelizmente não existem estudos mais aprofundados sobre essa inserção clerical nos níveis e instâncias mais locais (por exemplo, sobre a ocupação de cargos de vereador), o que permitiria avaliar as variações desse fenômeno a nível nacional e local. Caberia ressaltar, no entanto, que as restrições às atividades políticas do clero, certamente um dos pontos de convergência entre as iniciativas do Estado e de Roma, e a consequente diminuição nos efetivos das assembleias legislativas, significaram primeiramente um afastamento das instâncias convencionais da política (cargos, eleições, postos na burocracia, partidos) e não necessariamente um afastamento do político. No que tange ao presente estudo, a maior parte das trajetórias de sucesso examinadas mostram claramente que o posto clerical ainda constituía um Espaço de reconversão de recursos diversos para a atuação na política, o que não significa dizer que o sentido desse engajamento não tivesse sofrido variações conforme o agente e o espaço em questão. Sendo parte de uma ilha de letrados e dispondo de prestígio junto às camadas sociais mais desprovidas de recursos culturais, os sacerdotes estavam, na realidade, em condições de mobilizar diversas das competências apreendidas no espaço eclesial, tais como as técnicas de fala, de redação e de manipulação da assembleia (as missas são um exemplo disso), para aumentar suas chances de inserção e/ou manipulação com êxito no jogo político. Não estranha então que das paróquias mais periféricas, ao centro administrativo da diocese, vários religiosos tenham adentrado em carreiras públicas. Isso que certamente aumentava as chances de ascensão interna no espaço hierárquico. 


\section{Três trajetórias de sucesso no clero}

Manoel Tavares da Silva nasceu em Guimarães em 1829. Filho de comerciante, inicia seus estudos no seminário de Santo Antônio aos 14 anos de onde, após concluir o curso de humanidades, segue para Coimbra, em cuja universidade se bacharelou em Teologia Dogmática em 1853, aos 24 anos. De retorno à São Luís, e antes mesmo de ter concluído todas as etapas de ordenação (ele tinha recebido somente as chamadas ordens menores), foi colocado em um canonicato da Catedral. Quando obteve a sua ordenação em 1854, quase que simultaneamente a seu irmão mais jovem, Antônio Tavares da Silva, já era reconhecido por sua "cultura e aprimorada educação". Raros sacerdotes apresentaram uma ascensão pelos postos dentro e fora da hierarquia quanto Manoel Tavares: lente de dogma e grego, reitor do seminário, examinador sinodal, Chantre do Cabido em 1871, Arcediago em 1872, Vigário Geral e Vigário Capitular, etc. Reconhecido ainda por seu talento oratório e sua erudição, publicou o Manual Eclesiástico em 1860. “Com Fr. Vicente de Jesus fundou o Christianismo, de breve duração, e O Paiz, após propriedade de Tehmístocles Aranha e colaborou em "A Fé" - Deputado provincial, foi presidente da Assembléia, Comendador da "Ordem da Rosa", do Brasil, e da "Ordem de Cristo", de Portugal" (PACHECO, 1969, p. 441). É difícil não ver essa ascensão de Manoel Tavares da Silva associada aos contatos e prestígio que mantinha entre o mações, entre os quais gozava do grau de "Rosa-Cruz", e pelas relações que conseguiu estabelecer com agentes bem situados na hierarquia. Juntamente com o sacerdote Raimundo da Purificação dos Sanctos Lemos, tornou-se amigo próximo do Bispo Dom Luiz da Conceição Saraiva, com o qual chegaram a viajar em 1867 para conhecer os "grandes centros da civilização" (Roma, Lisboa, Madrid, Bordeaux, Paris). Morre no seu sítio em 1907.

Tolentino Guedelha Mourão nasceu em Passagem Franca em 1844. Filho de lavrador, faz seus estudos nos seminários de Nossa Senhora das Mercês e de Santo Antônio. Através da lei no 703 (23/07/1864), foi-lhe concedido estudar ciên- 
cias teológicas no seminário de S. Sulpicio em Paris. Ordenado sacerdote em 1868, seguiu para Roma onde obteve o título de doutorado em teologia em 1870. De retorno a São Lui, fora imediatamente designado como Lente de Cânones do Seminário de Santo Antônio. Já em 1871 é convocado pelo Bispo do Pará, Dom Macedo Costa, para auxiliá-lo na reforma da diocese. Durante o conflito religioso conhecido como a Questão Religiosa, esteve entre os sacerdotes mais ativos em Belém. Quando foi convocado para o Maranhão pelo bispo Dom Antonio Candido Alvarenga (1878-1898), a fim de atacar com vigor o relaxamento dos costumes do clero maranhense, já ostentava o título de "o mais reacionário dos padres do norte". Braço direito do bispo Alvarenga e com ascendência sobre o mesmo, Mourão destacou-se pelo acúmulo de posições centrais na Igreja local: Vigário Geral, Provisor e Juiz de Gênere e dos Casamentos, Vigário Capitular, Monsenhor e Prelado doméstico, Arcipreste da Cathedral, reitor e professor do Seminário Maior, etc. A notoriedade adquirida por Mourão, entretanto, não se restringia ao espaço eclesiástico: fora também Deputado estadual e federal pelo Maranhão, presidindo a Constituinte Estadual em 1892, sendo presidente da Assembléia Legislativa por duas legislaturas seguidas. Foi ainda o fundador do Partido Católico que depois fora integrado ao Partido Conservador (REIS, 1992). Foi um dos principais redatores do Jornal A civilisação, juntamente com os Padres Osório Athaíde Cruz e Raimundo Alves da Fonseca, que já havia se envolvido em diversas polêmicas locais. Fez parte ainda do Instituto Histórico e Geográfico Brasileiro. Combinados, todos esses elementos ajudam a entender como a figura de Tolentino Guedelha Mourão dominou o espaço católico local, servindo tanto de referência para novas gerações, que poderiam tomar o seu percurso como um dos altos lugares do exercício clerical e beneficiar-se do incentivo que dava à realização de estudos eclesiásticos em Paris, quanto suscitar conflitos mais ou menos velados com sacerdotes cujas propriedades os ligavam a modos de socialização distintos. É o que se mostra com clareza através da crise que acometeu os seminários locais, quando um conflito entre modos de geração diferentes provocou o êxodo de sacerdotes vinculados por relações de amizade em direção à diocese do Rio de Janeiro. 0 radical Mourão morreu em 1904. 
Leopoldo Damasceno Gerreira nasceu em Oeiras, Piauí, em 1857. Estudou no seminário de São José no Rio de Janeiro e no de Santo Antônio, em São Luís, de onde seguiu para Paris em 1882. Fez parte de um grupo de jovens sacerdotes de origem humilde, praticamente todos eles dispensados de impedimentos canônicos, e que se beneficiaram da abertura de possibilidades de passagem pelo estrangeiro para obtenção de formação religiosa. Formou-se em Direito Eclesiástico em 1883. De volta ao Maranhão em 1887 foi nomeado Cônego da Catedral e professor de História Eclesiástica, no Seminário de Santo Antonio. Em 1892, obteve por concurso a cadeira de francês, tornada comum, em 1893, ao Liceu e à Escola Normal do Estado. Entre 1893 e 1894 fez parte do "Conselho Superior da Instrução Pública" e em 1896 passou a lente de latim do Liceu, em substituição ao catedrático que se ausentou. Foi Deputado Estadual nas primeiras legislaturas da República. Faleceu em 1906.

Fonte: Conduru Pacheco (1969) e fontes diversas recolhidas pelo autor.

\section{Considerações finais}

Os resultados apresentados desse estudo prosopográfico sobre os membros da hierarquia eclesiástica durante a segunda metade do século XIX no bispado do Maranhão mostram que houve uma ligeira tendência à diversificação do acesso ao corpo eclesial. Com efeito, paralelamente a uma diminuição do peso das "grandes famílias", consequência do declínio da atração exercida pela elite eclesiástica sobre diferentes frações dos grupos dirigentes, assistiu-se a um incremento na representação de agentes vindos de pequenas comunidades de zonas rurais relativamente pobres do interior, ou mesmo de ofícios dos grupos dominados, cujo acesso à carreira eclesial significava uma possibilidade de ascensão social. Embora essa maleabilidade institucional não fosse novidade - como vimos, pelo menos desde o século XVIII era possível burlar os meios legais de controle do recrutamento - o que havia de novo no final do século XIX é que adquirir o 
estatuto de sacerdote se tornara um investimento cada vez mais laborioso e controlado pela instituição. Assim, num momento em que novas possibilidades de reconversão se abriam às elites, isso pode ajudar a explicar também o direcionamento dos herdeiros de famílias abastadas para outros domínios sociais, cujo ingresso gerasse maiores dividendos simbólicos e materiais e exigisse menores investimentos.

Seja como for, as alterações mais decisivas foram certamente a criação e a reforma dos seminários que ao mesmo tempo em que geraram um espaço que colocava lado a lado agentes com disposições e aspirações diversas (incentivando a competição interna), provocaram uma crescente uniformização da instituição. Além disso, a exigência de um maior investimento em tempo e energia dos pretendentes ao sacerdócio significou também a valorização do emprego de critérios de seleção mais internos à esfera eclesial. É verdade que, sem ser tradicional, o modelo de recrutamento ainda era baseado em mecanismos híbridos de seleção (capital social, relações baseadas na reciprocidade, conexões com a esfera política). Todavia, sem revolucionar o sistema como um todo, parece-me que o principal impacto dessas inovações institucionais foi o de suscitar uma tendência à convergência entre as características dos agentes e as expectativas objetivas associadas ao posto. Essa conformação, ou seja, essa adesão aos valores dominantes, aparece com mais evidência entre os alunos brilhantes oriundos de categorias sociais modestas cujas chances de ascensão pela carreira eclesiástica eram mais remotas outrora e cujas propriedades os levavam a investirem tudo na instituição à qual eles deviam tudo. Assim, fortemente ligados ao sistema de formação sacerdotal, aos seus valores, e gozando de benefícios em virtude de "boas relações" construídas ao longo de seus trajetos com superiores hierárquicos, como dizia Pierre Bourdieu (1987), esses oblatos eram inclinados ao papel de "gestores zelosos e guardiões da instituição", mais sensíveis que eram ao imperativo de defesa do catolicismo na sociedade, isso que poderia assumir diferentes significados e formas 
na configuração analisada, indo desde a restrição do escopo de atividades, passando pela inserção em combates nos periódicos locais até mesmo pela entrada na vida política. Sem desvalorizar os recursos e possibilidades abertas pela própria história da instituição e do posto, é sobre a base dessa transformação morfológica e organizacional da Igreja que se constituíram novas formas de relação com o mundo da cultura e da política.

Referências

Fontes primárias:

ARQUIVO PÚBLICO DO ESTADO DO MARANHÃO, SÃO LUÍS - MA (docu-
mentos impressos e manuscritos). Arquivo Público do Estado do Maranhão, Acervo da Arquidiocese do Maranhão, AUTOS de Patrimônio, Caixa 40 (1878-1902) - Docs (1485 a 1523) Maços (192-97).

Arquivo Público do Estado do Maranhão, Acervo da Arquidiocese do Maranhão, AUTOS de Habilitação de Gênere, Caixas 57 a 62 (1850-1905) - Docs (1908 a 2073) - Maços (288-323).

Arquivo Público do Estado do Maranhão, Acervo da Arquidiocese do Maranhão, AUTOS de Vita et Moribus, Caixas 77 a 78 (1853-1869) - Docs (2508 a 2562)- Maços (398-406);

Arquivo Público do Estado do Maranhão, Acervo da Arquidiocese do Maranhão, AUTOS de Oposição, Caixas 203-207 (1852-1889) - Docs (6681-6821) - Maços 902-922.

Arquivo Público do Estado do Maranhão, Acervo da Arquidiocese do Maranhão, AUTOS de Colação, Caixas 170-171 (1796-1887) - Docs. (5240 a 5280), Maços (766 a 770).

Arquivo Público do Estado do Maranhão, Acervo da Arquidiocese do Maranhão, Setor de Códices, Livro de Registro de Ordenações (n.- 177; 1845-1894);

Arquivo Público do Estado do Maranhão, Acervo da Arquidiocese do Maranhão, Setor de Códices, Livro de Registros Gerais da Câmara Episcopal (n.o $207 ; 1872-1878$ ) 
Arquivo Público do Estado do Maranhão, Acervo da Arquidiocese do Maranhão, Setor de Códices, LIVRO de Registro de diversos termos (matrícula, oposição, aceitação de residência, exame e aprovação, termo de juízo e assistência) (n. ํㅡㄹ 17 ; 1845-1872).

Arquivo Público do Estado do Maranhão, Acervo da Arquidiocese do Maranhão, Setor de Códices, LIVRO de Registro dos documentos expedidos e recebidos pelo bispado (n. 0 221; 1877-1893).

Arquivo Público do Estado do Maranhão, Acervo da Arquidiocese do Maranhão, Setor de Códices, LIVRO de correspondência recebida pelo governador do Bispado dos Seminários de Santo Antônio e Mercês (n.o 276 - 1862-1866; n. 277 - 1865-1869 e n.o 278 - 1868-1873).

Arquivo Público do Estado do Maranhão, Acervo da Arquidiocese do Maranhão, Setor de Códices, LIVRO de Registro de Colações, ofícios e outros (n. ${ }^{\circ}$ 302 ; 1853-1899)

Arquivo Público do Estado do Maranhão, Acervo da Arquidiocese do Maranhão, Setor de Códices, LIVRo de Registro das Freguesias do Maranhão e Piauí (n. - 335, 1872)

Arquivo Público do Estado do Maranhão, Acervo da Arquidiocese do Maranhão, Setor de Códices, LIVRO de Registro das Freguesias do Maranhão e seus respectivos Colados e Coadjutores (n. ${ }^{-3}$ 36; sem data)

Arquivo Público do Estado do Maranhão, Acervo da Arquidiocese do Maranhão, Setor de Códices, LIVRO de Registro das Freguesias com data de ereção da capela (n. -337 ; sem data).

\section{BIBLIOTECA PÚBLICA ESTADUAL BENEDITO LEITE, SÃO LUÍS - MA}

Jornais:

Jornal O PENSADOR 1880-1882

Jornal CIVILISAÇÃO 1880-1890

Jornal O ELESIÁSTICO 1852-1862

\section{Bibliografia}

BERAUD, Celine. Le métier de prêtre: approche sociologique. Paris: Editions Ouvrières, 2006. 
BOURDIEU, Pierre \& SAINT-MARTIN, Monique de. La sainte famille: l'episcopat français dans le camp du pouvoir. Actes de la Recherche en Sciences Sociales, nov. 1987. p. 02-53.

BOURDIEU, Pierre \& PASSERON, Jean Claude. A Reprodução. Rio de Janeiro: Bertrand Brasil, 1978.

. Le corps et le sacré. Actes de la Recherche en Sciences Sociales, Année 1994, Volume 104, n.․ㅜㅅㅣ p. 2-2.

A Economia das Trocas Linguísticas. São Paulo: EDUSP, 1996.

O Poder Simbólico. Rio de Janeiro, Bertrand Brasil, 2007.

. A produção da crença: contribuição para uma economia dos bens simbólicos. Porto Alegre/RS, Zouk, 2006.

BOLTANSKI, Luc. L'espace positionnel: multiplicité des positions institutionnelles et habitus de classe. Revue de sociologie Française, Année 1973, Volume 14, n. .01 , p. 3-26.

BULSF, Neithard. Sobre o objeto e o método da prosopografia. Politeia: Hist. e Soc., Vitória da Conquista, v. 3, n.․ 01, p. 47-67, 2005.

BRUNEAU, Thomas C. 0 catolicismo brasileiro em época de transição. São Paulo: Loyola, 1974.

Campiche Roland, Bovay C. Prêtres, pasteurs, rabbins. Bibliographie thématique. In: Archives des sciences sociales des religions. N. 48/1, 1979. pp. 133-183. http://www.persee.fr/web/revues/home/prescript/article/ assr_0335-5985_1979_num_48_1_2194

CHARLE, Christophe. Homo Historicus. Reflexions sur l'histoire, les historiens e les sciences sociales. Armand Colin, Paris, 2013.

. Situation spatiale et position sociale. Actes de la Recherche en Sciences Sociales, 1977, Volume 13, n.․ㅜ 01, p. 45-59.

Naissance d'un grand corps. Actes de la Recherche en Sciences

Sociales, 1982, Volume 42, n. $\stackrel{0}{01}$, p. 3-17.

CARVALHO, José Murilo de. A construção da ordem: a elite política imperial; Teatro de Sombras: a política imperial. 2. ed.rev. Rio de Janeiro: Editora UFRJ, Relume-Sumará, 1996.

CORADINI, Odaci Luiz. Grandes Famílias e Elite 'profissional' na medicina no Brasil. História, Ciências, Saúde - Manguinhos, III (3), 425-466, Nov-Feb. 1997a.

O recrutamento da elite, as mudanças na composição social e a 'crise da medicina' no Rio Grande do Sul. História, Ciências, Saúde - Manguinhos, IV (2), 165-286, Jul-Out. 1997b. 
COSTA, Yuri. Entre barões e escravos: agonia e morte de Celso Magalhães. In: COSTA, Yuri \& GALVES, Marcelo Cherche. Maranhão: ensaios de biografia e história. São Luís: Café e Lapis, Editora UEMA, 2011.

LAGROYE, Jacques. La vérité dans l'Église catholique. Contestations e restauration d'un régime d'autorité. Éditions Bellin, 2006.

Appartenir à une institution: catholiques en France aujourd'hui. Ed. Economica, Paris, 2009.

LAGROYE, Jacques; OFFERLÉ, Michel. (Orgs.) Sociologie de l'institution. Paris: Belin, 2011.

HEINZ, Flávio (org.). Por outra história das elites. Rio de Janeiro: Editora FGV, 2006.

MARTINS, Karla Denise. Civilização Católica: D. Macedo Costa e o desenvolvimento da Amazônia da segunda metade do século XIX. Revista de História Regional 7(1): 73-103, Verão 2002.

MARQUES, César Augusto. Dicionário Histórico-Geográfico da Província do Maranhão. 3ํㅡㄹição. São Luís: SUDEMA, 1970.

. A Igreja no Maranhão. São Luís: Fundação Cultural do Maranhão, 1977.

MENDONÇA. Pollyanna Gouveia. Parochos imperfeitos: Justiça Eclesiástica e desvios do clero no Maranhão setecentista. Tese de História apresentada à Universidade Federal Fluminense, UFF, Brasil, 2011.

Sacrílegas Famílias: conjugalidades clericais no bispado do Maranhão no século XVIII. Dissertação de Mestrado em História apresentada à Universidade Federal Fluminense, UFF, Brasil, 2007.

MEIRELLES, Mário Martins. História da Arquidiocese de São Luís do Maranhão. São Luís: Universidade do Maranhão/SIOGE, 1977.

MÉRIAN, Jean-Yves. ALuísio Azevedo, vida e obra (1857-1913). Rio de Janeiro: Espaço e Tempo, 1988.

MICELI, Sergio. A elite eclesiástica Brasileira. Rio de Janeiro: Ed. Bertrand Brasil, 1988.

MONTEIRO, Nuno Gonçalves. Mobilidade social nas carreiras eclesiásticas em Portugal (1500-1820). Análise social, vol. 27, n.ํㅜ 165, 2003, p. 1213-1239.

MUEL-DREYFUS, Fracine. Le Métier d'educateur. Les instituteurs de 1900, les éducateurs specialisés de 1968. Paris: Minuit, 1983.

NERIS, Wheriston Silva. As bases sociais do recrutamento de elites eclesiásticas no Bispado do Maranhão (1850-1900). 2009. 198 fls. Dissertação 
(Mestrado em Ciências Sociais) - Universidade Federal do Maranhão São Luís, 2009.

. 0 sacerdote paradigma: a trajetória do padre Raimundo Alves da Fonseca (1842-1883). In: COSTA, Yuri \& GALVES, Marcelo Cherche. Maranhão: ensaios de biografia e história. São Luís: Café e Lapis; Editora UEMA, 2011.

PACHECO, D. Felipe Condurú. História Eclesiástica do Maranhão. São Luís: Departamento de Cultura do Estado, 1969.

D. Luís de Brito: o primeiro arcebispo de Olinda. Rio de Janeiro: Departamento de Impresa Nacional, 1954.

PINTO, Louis. Experiência vivida e exigência científica de objetividade. MERLLIÉ, D. et. al. (org.). Iniciação à prática sociológica. Petrópolis, Vozes, 1996.

. L'armée, le contingent et les classes sociales. Actes de la Recherche em Sciences Sociales, 975, Volume 1, Número 3.

RODRIGUEZ, Angel Veiga. Crítica ao Positivismo na Imprensa católica maranhense. São Luís: SECMA, 1982

ROY, Jean. Le clergé nicolétain, 1885-1904: aspects sociographiques. Revue d'histoire de l'Amérique française, vol. 35, n.ํㅜ 1981, p. 383-395.

SALINAS ARANEDA, Carlos. La actuación de los Obispos en la supresión del fuero eclesiástico en Chile en el siglo XIX. Rev. Estud. Hist.-Juríd. 2006, no. 28.

SEIDL, Ernesto. A espada como "vocação": padrões de recrutamento e seleção das elites do exército no Rio Grande do Sul (1850-1930). Dissertação de Mestrado apresentada ao Programa de Pós-Graduação em Ciência política, Universidade Federal do Rio Grande do Sul, Porto Alegre, 1999.

. A elite eclesiástica no Rio Grande do Sul. Tese (Doutorado em Ciência Política) - Programa de Pós-Graduação em Ciência política, Universidade Federal do Rio Grande do Sul, Porto Alegre, 2003.

. Sociologia histórica do Estado: Igreja e construção nacional no Brasil e na Argentina. TOMO, ano IX, n.․ 09, p. 30-61, 2006.

SILVA, D. Francisco de Paula. Apontamentos para a História Eclesiástica do Maranhão. Bahia: Typographia de São Francisco, 1922.

SUAUD, Charles. Contribution à une sociologie de la vocation: destin religieux et projet scolaire. Revue Française de Ssociologia, 1974, Volume 15, Número 1.

VERNARD, Marc. Pour une sociologie du clergé au XVIe siècle: recherche sur le recrutement sacerdotal dans la province d'Avignon. Annales, 1968, Volume 23, Número 5, p. 987-1016. 
VIDE, Dom Sebastião Monteiro da. Constituições Primeiras do Arcebispado da Bahia. (Impressas em Lisboa no ano de 1719, e em Coimbra em 1720. São Paulo): Tip. 2 de Dezembro, 1853.

WEISZ, George. Les transformations de l'élite médicale en France. Actes de la Recherche en Sciences Sociales. Vol. 74, septembre 1988, p. 33-46. 